\title{
Selective Episiotomy: Indications, Techinique, and Association with Severe Perineal Lacerations
}

\section{Episiotomia seletiva nos dias atuais: indicações, técnica e associação com lacerações perineais graves}

\author{
Mário Dias Corrêa Junior ${ }^{1,2}$ Renato Passini Júnior ${ }^{3,4}$ \\ ${ }^{1}$ Faculty of Medicine, Universidade Federal de Minas Gerais (UFMG), \\ Belo Horizonte, MG, Brazil \\ 2 Department of Maternity, Hospital das Clínicas, UFMG, Belo \\ Horizonte, MG, Brazil \\ 3 Department of Tocogynecology, Faculdade de Ciências Médicas, \\ Universidade Estadual de Campinas (Unicamp), Campinas, SP, Brazil \\ ${ }^{4}$ Division of Obstetrics, Hospital da Mulher Prof. Dr. José Aristodemo \\ Pinotti, Campinas, SP, Brazil
}

Rev Bras Ginecol Obstet 2016;38:301-307.

\author{
Address for correspondence Mário Days Corrêa Junior, MD, \\ Departmento de Ginecologia e Obstetrícia, Faculdade de Medicina, \\ UFMG, Av. Prof. Alfredo Balena, 190, sala 217, Santa Efigênia, 30130- \\ 100 - Belo Horizonte, MG, Brazil (e-mail: mariodcorrea@ufmg.br).
}

\begin{abstract}
Keywords

- episiotomy

- perineal lacerations

- obstetrical delivery

Introduction Episiotomy is a controversial procedure, especially because the discussion that surrounds it has gone beyond the field of scientific debate, being adopted as an indicator of the "humanization of childbirth". The scientific literature indicates that episiotomy should not be performed routinely, but selectively.

Objectives To review the literature in order to assess whether the implementation of selective episiotomy protects against severe perineal lacerations, the indications for the procedure, and the best technique to perform it.

Methods A literature search was performed in PubMed using the terms episiotomy or perineal lacerations, and the filter clinical trial. The articles concerning the risk of severe perineal lacerations with or without episiotomy, perineal protection, or episiotomy techniques were selected.

Results A total of 141 articles were identified, and 24 of them were included in the review. Out of the 13 studies that evaluated the risk of severe lacerations with and without episiotomy, 5 demonstrated a protective role of selective episiotomy, and 4 showed no significant differences between the groups. Three small studies confirmed the finding that episiotomy should be performed selectively and not routinely, and one study showed that midline episiotomy increased the risk of severe lacerations. The most cited indications were primiparity, fetal weight greater than $4 \mathrm{~kg}$, prolonged second stage, operative delivery, and shoulder dystocia. As for the surgical technique, episiotomies performed with wider angles $\left(>40^{\circ}\right)$ and earlier in the second stage (before "crowning ") appeared to be more protective.

Conclusions Selective episiotomy decreases the risk of severe lacerations when compared with the non-performance or the performance of routine episiotomy. The use of a proper surgical technique is fundamental to obtain better results, especially in relation to
\end{abstract}

received January 29, 2016 accepted May 3, 2016
DOI http://dx.doi.org/ 10.1055/s-0036-1584942. ISSN 0100-7203.
Copyright ( $\odot 2016$ by Thieme Publicações License terms Ltda, Rio de Janeiro, Brazil

() (1) $\odot \circledast$ 


\section{Resumo}

Palavras-chave

- episiotomia

- lacerações perineais

- parto obstétrico the angle of incision, the distance from the vaginal introitus, and the correct timing for performing the procedure. Not performing the episiotomy when indicated or not applying the correct technique may increase the risk of severe perineal lacerations.

Introdução A episiotomia é um procedimento controverso, devido, em parte, à discussão sobre sua realização ter ultrapassado o campo do debate cientifico, sendo adotada como indicador associado com a "humanização do parto." A literatura mostra que a episiotomia não deve ser realizada rotineiramente, mas de forma seletiva. Questões relativas à sua indicação, técnica de realização e associação com lacerações perineais graves são objeto de amplo debate e pesquisa.

Objetivos Revisar a literatura para avaliar se a realização da episiotomia seletiva protege contra lacerações perineais graves, quais são suas indicações, e qual a melhor técnica para realizar este procedimento.

Método Foi realizada busca no PubMed com os termos episiotomy ou perineal lacerations utilizando o filtro clinical trial. Foram selecionados os artigos que tratavam do risco de lacerações perineais graves com e sem episiotomia, ou de técnicas de proteção perineal ou de episiotomia.

Resultados Foram identificados 141 artigos, dos quais 24 foram incluídos na revisão. Dos 13 estudos que avaliaram o risco de lacerações graves com e sem episiotomia, 5 demonstraram o papel protetor da episiotomia seletiva, e 4 não mostraram diferenças significativas entre os grupos. Três pequenos estudos confirmaram o achado de que a episiotomia deve ser realizada seletiva e não rotineiramente, e um estudo mostrou que a episiotomia mediana aumenta o risco de lacerações graves. Quanto às indicações, as mais citadas foram a primiparidade, peso fetal maior do que $4 \mathrm{~kg}$, período expulsivo prolongado, parto operatório e distocia de ombro. Quanto à técnica, episiotomias realizadas com ângulos mais abertos $\left(>40^{\circ}\right)$ e mais precocemente no período expulsivo (antes do "coroamento") parecem ser mais protetoras.

Conclusões Episiotomias seletivas reduzem o risco de lacerações graves comparativamente à não realização de episiotomia ou à realização de episiotomia rotineira. Para esse resultado, é fundamental a utilização de técnica operatória correta, principalmente em relação ao ângulo de inclinação e distância da fúrcula vaginal, além do momento de sua realização. Deixar de realizar a episiotomia, com a técnica correta e quando bem indicada, pode aumentar o risco de lacerações perineais graves.

\section{Introduction}

Few medical procedures have been the object of such controversy in recent years as episiotomy. Described in the 18th century, episiotomy is a surgical incision in the perineal region to widen the birth canal in its final portion, facilitating the exit of the fetal head. ${ }^{1}$

Historically, episiotomy began to be extensively used after a publication by DeLee ${ }^{2}$ in 1920 , in which he defended not only the routine use of episiotomy, but also the application of prophylactic relief forceps. As DeLee ${ }^{2}$ was one of the most influential obstetricians of his time, such practice was expanded during the greater part of the twentieth century, until 1983, when two American epidemiologists, Stephen Thacker and David Banta, ${ }^{1}$ published a review pointing out that there was no evidence supporting the benefits or risks of episiotomy. After this observation, several studies were performed worldwide, culminating in a meta-analysis by the Cochrane Library ${ }^{3}$ published in 2009. This publication, which initially included seven studies (another was added subsequently), showed that the selective use of episiotomy was preferable to the routine use, since the group that was subjected to routine episiotomy had a greater incidence of lacerations of the posterior wall (odds ratio, OR: 0.88; confidence interval, CI: 0.84-0.92) and severe perineal lacerations (third- and fourth-degree) (OR: $0.67 \mathrm{CI}: 0.49-0.91$ ), with no benefits with regards to other aspects such as decrease in low Apgar score (-Table $\mathbf{1}$ ).

After the publication of this review, the rates of episiotomies decreased dramatically worldwide. Goldberg et $\mathrm{al}^{4}$ reported a decrease from $69.3 \%$ in 1983 to $19.4 \%$ in 2000 in the US. In the United Kingdom, the rates decreased from $19.1 \%$ in 2000 to $15.1 \%$ in $2012 .^{5}$

On the other hand in places where the decrease in episiotomy rates was very significant, there was an increase in the occurrence of severe perineal lacerations. Räisänen et 
$\mathrm{al}^{6}$ evaluated 384,638 births and demonstrated that the decrease in episiotomy rates in Finland from $56.7 \%$ to $45.5 \%$ resulted in a $1.3 \%$ to $1.7 \%$ increase in severe perineal lacerations, while Gurol-Uganci et $\mathrm{al}^{5}$ also demonstrated that serious lacerations tripled in the United Kingdom (1.8\% to $5.9 \%$ ) associated with the decrease in the number of episiotomies performed.

Severe perineal lacerations affect the anal sphincter (third-degree) and the rectal mucosa (fourth-degree), and have the potential to cause important sequelae in patients. Up to $10 \%$ of patients with severe perineal lacerations will develop fecal incontinence. Flatus incontinence may occur in $29 \%$ to $53 \%$ of these women, and many can also present internal anal sphincter gaps. ${ }^{7}$

Given the increasing rates of potentially severe complications during the assistance of vaginal delivery, and since it has already been demonstrated that the use of selective episiotomy is preferred over the routine use, the objectives of this review were as follows: to review the most recent literature to evaluate the relationship between severe perineal lacerations and episiotomy; to identify the risk factors for severe perineal lacerations at childbirth; to assess whether the implementation of selective episiotomy protects against severe perineal lacerations; and to identify the best technical guidelines for performing episiotomy.

\section{Methods}

A search was performed in the PubMed database using the terms episiotomy or perineal lacerations, and using the filter clinical trial, from studies published between 2005 and 2015. A total of 141 articles were identified that fitted the criteria. All abstracts were reviewed, and 24 were selected that dealt with the risk of severe perineal lacerations with or without episiotomy, perineal protection techniques, or episiotomy. The bibliographic references of the selected studies were also reviewed to search for articles of interest that did not appear in the initial literature search.

\section{Results}

Selective Episiotomy and Severe Perineal Lacerations In an attempt to fulfill the first objective (whether selective episiotomy protects against serious perineal lacerations), the studies listed in - Table $\mathbf{2}^{8-12,16,19-25}$ were analyzed. We can observe that there were contradictory results, but some studies pointed out that the selective use of episiotomy might reduce the rate of severe lacerations.

\section{Indications for Episiotomy}

To evaluate the indications for episiotomy, we reviewed the selected studies to identify risk factors for severe lacerations. The findings are summarized in - Table 3 . $^{8-18}$

Among the most often cited risk factors were primiparity, fetal weight higher than $4 \mathrm{~kg}$, prolonged second stage, operative delivery, and shoulder dystocia. Fetal suffering could not be properly assessed because all the randomized studies on the subject, as well as the observational studies that followed, considered fetal distress an indication for episiotomy. $^{3}$

\section{Episiotomy Technique}

In regards to the best surgical technique for episiotomy, we assumed that medio-lateral episiotomy was superior to midline episiotomy, as already demonstrated in previous studies. Therefore, we analyzed only those studies that assessed the technical aspects of medio-lateral episiotomy.

Andrews et $\mathrm{al}^{26}$ performed a prospective study that evaluated 254 patients. Of these, 98 (41\%) required episiotomy. Given that the correct incision angle for medio-lateral episiotomy suggested in the literature is between 40 and 60 degrees, the authors observed that only $22 \%$ of physicians and no midwife actually performed medio-lateral episiotomy. The average angle of episiotomy adopted by obstetricians was of 27 degrees and of 20 degrees by midwives.

In 2006, Eogan et $\mathrm{al}^{27}$ performed a case-control study assessing 54 patients with anal laceration and 46 control women who had undergone vaginal delivery 3 months previously. The authors observed that the angle of the episiotomy incision was significantly smaller in the patient group when compared with the control group (30 degrees versus 38 degrees, $p<0.001$ ). They also observed that the risk of serious injury decreased progressively with the increase of the angle of episiotomy, being of $0.05 \%$ when the angle was above 45 degrees, and of $10 \%$ at angles smaller than 25 degrees (OR: 9.7). They concluded that to improve the degree of protection of medio-lateral episiotomy, incisions should always be made at angles greater than 45 degrees. ${ }^{27}$

Table 1 Main findings of the meta-analysis comparing selective versus routine episiotomy

\begin{tabular}{|l|l|l|l|}
\hline Condition assessed & N & OR & Cl \\
\hline Occurrence of any subsequent laceration & 2,079 & 0.88 & $0.84-0.92$ \\
\hline Severe perineal laceration & 4,404 & 0.67 & $0.49-0.91$ \\
\hline Occurrence of any previous laceration & 4,896 & 1.84 & $1.61-2.10$ \\
\hline Perineal pain at discharge & 2,422 & 0.72 & $0.65-0.81$ \\
\hline First minute APGAR score $<7$ & 3,908 & 1.04 & $0.76-1.43$ \\
\hline
\end{tabular}

Abbreviations: $\mathrm{Cl}$, confidence interval; $\mathrm{N}$, number of patients included in the analysis; OR, odds ratio. 
Table 2 Studies included in the evaluation of the relationship between performance of episiotomy and occurrence of perineal lacerations

\begin{tabular}{|c|c|c|c|}
\hline Study & $\mathbf{N}$ & Method & Result \\
\hline Revicky et al ${ }^{8}$ & 10,314 & $\begin{array}{l}\text { Cross-sectional study of } 10,314 \\
\text { patients submitted to vaginal } \\
\text { delivery in England }\end{array}$ & $\begin{array}{l}\text { The rate of third and fourth-degree lacerations was } \\
3.2 \% \text {, and not performing episiotomy was a risk } \\
\text { factor: OR: } 1.4 ; \mathrm{Cl}: 1.21-1.98\end{array}$ \\
\hline Landy et al ${ }^{9}$ & 82,267 & $\begin{array}{l}\text { Analysis of electronic medical charts } \\
\text { of } 19 \text { hospitals in } 7 \text { years }\end{array}$ & $\begin{array}{l}\text { The rate of third- and fourth-degree lacerations } \\
\text { was of } 5.8 \% \text { in primiparous, and of } 0.6 \% \text { in mul- } \\
\text { tiparous women; } 78 \% \text { were midline episiotomies. } \\
\text { The episiotomy was a risk factor both in nulliparous } \\
\text { (OR; } 2.4 ; \mathrm{Cl}: 2.1-2.7 \text { ) and multiparous women (OR: } \\
4.4 ; \mathrm{Cl}: 3.3-5.8)\end{array}$ \\
\hline Aukee et al ${ }^{10}$ & 9,178 & $\begin{array}{l}\text { Retrospective analysis of } 9,178 \text { births } \\
\text { in Finland }\end{array}$ & $\begin{array}{l}\text { The rate of third- and fourth-degree lacerations } \\
\text { was of } 1.0 \% \text {, and the episiotomy was a protective } \\
\text { factor (OR: } 0.37 ; \mathrm{Cl}: 0.20-0.70)\end{array}$ \\
\hline Moini et al ${ }^{11}$ & 283 & $\begin{array}{l}\text { Patients randomized for selective or } \\
\text { routine episiotomy in Iran }\end{array}$ & $\begin{array}{l}\text { The routine episiotomy group presented a higher } \\
\text { rate of third- and fourth-degree lacerations: } \\
13.14 \% \text { versus } 2.05 \%\end{array}$ \\
\hline Eskandar and Shet $^{12}$ & 3,038 & $\begin{array}{l}\text { Review of records of 3,038 vaginal } \\
\text { births that occurred in a 2-year period } \\
\text { in England }\end{array}$ & $\begin{array}{l}\text { The rate of third and fourth-degree lacerations was } \\
\text { of } 1.58 \% \text {, and the medio-lateral episiotomy showed } \\
\text { a non-significant trend to protection: OR: } 0.35 \text {; Cl: } \\
0.08-1.4\end{array}$ \\
\hline Räisänen et al ${ }^{16}$ & 303,758 & $\begin{array}{l}\text { Assessment of Finnish medical } \\
\text { records }\end{array}$ & $\begin{array}{l}\text { The rate of serious perineal lacerations ranged } \\
\text { from } 0.2 \% \text { in multiparous women to up to } 2.3 \% \text { in } \\
\text { primiparous women. The episiotomy was a pro- } \\
\text { tective factor in primiparous women (OR: } 0.77 ; \mathrm{Cl} \text { : } \\
0.69-0.86 \text { ), and a risk factor in multiparous women } \\
\text { (OR: } 1.61 ; \mathrm{Cl}: 1.14-2.29 \text { ) }\end{array}$ \\
\hline Fritel et al ${ }^{19}$ & 627 & $\begin{array}{l}\text { Comparison between patients at- } \\
\text { tending two French hospitals. The } \\
\text { first with a policy of selective, and the } \\
\text { second, routine episiotomy }\end{array}$ & $\begin{array}{l}\text { With no differences in urinary incontinence four } \\
\text { years after delivery. Fecal incontinence higher in } \\
\text { the routine episiotomy group }\end{array}$ \\
\hline Murphy et $\mathrm{al}^{20}$ & 317 & $\begin{array}{l}\text { Routine versus selective episiotomy } \\
\text { in patients with operative deliveries }\end{array}$ & $\begin{array}{l}\text { With no differences in serious lacerations, fecal or } \\
\text { urinary incontinence six weeks postpartum }\end{array}$ \\
\hline Macleod et $\mathrm{al}^{21}$ & 1,360 & $\begin{array}{l}\text { Routine versus selective episiotomy } \\
\text { in patients with operative deliveries }\end{array}$ & $\begin{array}{l}\text { With no differences in serious lacerations or } \\
\text { shoulder dystocia. Episiotomy associated with in- } \\
\text { crease in infections and neonatal trauma }\end{array}$ \\
\hline de Leeuw et $a^{22}$ & 21,254 & $\begin{array}{l}\text { Patients with operative deliveries in } \\
\text { Holland }\end{array}$ & $\begin{array}{l}\text { The medio-lateral episiotomy strongly protected } \\
\text { against third- and fourth-degree lacerations in } \\
\text { patients submitted to vacuum extractor (OR: } 0.11 \text {; } \\
\mathrm{Cl}: 0.09-0.13 \text { ) and forceps (OR: } 0.08 \text {; Cl: } 0.07- \\
0.11 \text { ) }\end{array}$ \\
\hline Islam et $\mathrm{al}^{23}$ & 200 & $\begin{array}{l}\text { A randomized study comparing rou- } \\
\text { tine and selective episiotomy } \\
\text { (abstract only) }\end{array}$ & $\begin{array}{l}\text { Most common serious lacerations in the routine } \\
\text { episiotomy group }\end{array}$ \\
\hline Sulaiman et $\mathrm{al}^{24}$ & 171 & $\begin{array}{l}\text { Patients randomized for selective or } \\
\text { routine episiotomy in Malaysia } \\
\text { (abstract only) }\end{array}$ & $\begin{array}{l}\text { Serious lacerations were more common in the } \\
\text { routine episiotomy group (3.7\%) than in the se- } \\
\text { lective episiotomy group }(1.1 \%)\end{array}$ \\
\hline Hauck et $\mathrm{al}^{25}$ & 10,408 & $\begin{array}{l}\text { Retrospective analysis of medical } \\
\text { records in an Australian hospital } \\
\text { (abstract only) }\end{array}$ & $\begin{array}{l}\text { The rate of serious perineal laceration was of } 3 \% \text {. } \\
\text { The episiotomy was a protective factor in primip- } \\
\text { arous women (OR: } 0.54 \text {; Cl: } 0.39-0.74 \text { ), and a risk } \\
\text { factor in multiparous women (OR: } 2.01 \text {; Cl: } 1.18- \\
3.45 \text { ) }\end{array}$ \\
\hline
\end{tabular}

Kalis et $a^{28}$ prospectively evaluated 50 patients and observed that there was a decrease of 15 degrees of the incision angle on average, and this decrease was greater when the episiotomy was performed when the head was crowning. In this case, the angle of the suture line was decreased by 20 degrees. In other words, when the episiotomy was performed at an angle of 45 degrees during the final phase of the second stage, at the time of suture, the angle observed was of 25 degrees. They attributed this change to the birth canal being three- 
Table 3 Risk factors for severe perineal laceration

\begin{tabular}{|l|l|l|l|}
\hline Risk Factor & Number of studies & Lesser OR or RR & Higher OR or RR \\
\hline Maternal age $>35$ years & $2^{8,9}$ & $1.6(1.2-2.0)$ & $2.84(1.69-4.76)$ \\
\hline Primiparity & $5^{10-15}$ & $3.2(2.5-4.1)$ & $8.34(3.98-17.48)$ \\
\hline Gestational age $\geq 42$ weeks & $1^{11}$ & $3.62(1.28-10.21)$ & - \\
\hline Weight $\geq 3,500 \mathrm{~g}$ & $1^{9}$ & $3.8(2.5-5.9)$ & - \\
\hline Weight $\geq 4,000 \mathrm{~g}$ & $5^{8-10,14-16}$ & $2.12(1.64-2.72)$ & $12.92(2.77-60.11)$ \\
\hline Weight $\geq 4,500 \mathrm{~g}$ & $3^{9,11,17}$ & $4.42(2.68-7.27)$ & $10.5(5.4-20.6)$ \\
\hline Duration of the second stage $\geq 60$ minutes & $2^{9,14,16}$ & $1.32(1.18-1.47)$ & $1.52(1.11-2.10)$ \\
\hline Duration of the second stage $\geq 90$ minutes & $1^{11}$ & $2.95(1.39-6.27)$ & - \\
\hline Duration of the second stage $\geq 120$ minutes & $1^{9,16}$ & $1.42(1.11-1.82)$ & $1.7(1.5-2.0)$ \\
\hline Duration of the second stage $\geq 180$ minutes & $1^{9}$ & $2.0(1.7-2.4)$ & - \\
\hline Vacuum extractor & $8^{5,8-11,16-18}$ & $1.68(1.50-1.87)$ & $5.22(2.69-10.13)$ \\
\hline Forceps & $6^{5,8,9,13,16,17}$ & $1.95(1.39-2.75)$ & $6.3(5.57-7.64)$ \\
\hline Lithotomy position & $1^{14}$ & $2.02(1.58-2.59)$ & - \\
\hline Squatting position & $1^{14}$ & $2.05(1.09-3.82)$ & - \\
\hline Variety of OP presentation & $2^{12,18}$ & $1.34(1.22-1.46)$ & $69.8(14-84)$ \\
\hline Head circumference $>35 \mathrm{~cm}$ & $1^{14}$ & $1.57(1.23-1.99)$ & - \\
\hline Shoulder dystocia & $4^{5,8,17,18}$ & $1.33(1.16-1.53)$ & $1.98(1.11-3.54)$ \\
\hline
\end{tabular}

Abbreviations: OP, occipito-pubic; OR, odds ratio; RR, relative risk.

dimensional, causing distention in all directions, and suggested that the angles of the episiotomy should be greater, approaching 60 degrees. ${ }^{28}$

A Norwegian study ${ }^{29}$ evaluated 37 cases of laceration of the anal sphincter and 37 controls, and observed that episiotomy was associated with a lower risk of laceration when the final angles were between 30 and 60 degrees, the lenght was greater then $17 \mathrm{~mm}$, had a depth of more than $16 \mathrm{~mm}$ from the midline (perineal raphe), and the incision point began $9 \mathrm{~mm}$ further from the posterior fourchette (-Fig. 1).

In an article published in $2013,{ }^{30}$ a Spanish group reviewed 72 cases of operative delivery in which the patients

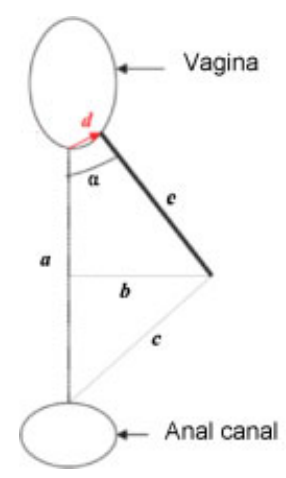

Lower rate of lacerations associated with:
Angle between $30^{\circ}$ and $60^{\circ}$
"d" $>9 \mathrm{~mm}$
"e" $>7 \mathrm{~mm}$
${ }^{\mathrm{a}} \mathrm{b} ">16 \mathrm{~mm}$

Fig. 1 Schematic view of the angulation in the episiotomy and the frequency of associated laceration. ${ }^{29}$ underwent episiotomy (36 with laceration of the sphincter and 36 without laceration). It was observed that the episiotomy with an angle greater than 20 degrees was a protective factor, decreasing the risk of serious injury by $87 \%$ (OR: 0.13 CI: 0.03-0.58). An episiotomy smaller than $15 \mathrm{~mm}$ and the distance from the edge of the episiotomy to the anus below $15 \mathrm{~mm}$ were risk factors.

Regarding the ideal timing for performing the episiotomy, we found there were no specific studies assessing this specific aspect, although a computational model study performed in 2010 with the objective of evaluating the forces to which the pelvic floor musculature was subjected during the passage of the fetal head indicated that the forces were progressively larger with the lowering of the head, reaching the maximum stretching point when the +3 plane of DeLee was reached $(+4 \mathrm{~cm}){ }^{31}$

\section{Discussion}

There is no doubt in the literature that episiotomy should be performed in a selective manner, not routinely. This observation has already been confirmed by several randomized and controlled studies, and is not discussed in this review. The issue is that the incorrect interpretation of such data has led some clinicians to believe that not performing episiotomy in any patient would be better than performing the procedure only selectively, with precise indications and the correct technique. Unfortunately, not performing episiotomy became, equivocally, a required element in what is called 
"naturalization" of childbirth, since this would require lower rates of intervention. The degree of misinformation about episiotomy has reached such a point that serious organizations have begun to consider its implementation as a form of "obstetric violence". 32

What many ignore is that just like any medical procedure, episiotomy has indications and surgical techniques that, when followed correctly, effectively protect women against serious lacerations that can lead to important sequelae such as anal incontinence. In our understanding, it is not possible to classify as violence a procedure that prevents severe sequelae when it is performed following the proper indications and techniques.

This review aimed to retrieve from the literature evidences about the protection of episiotomy against third- and fourth-degree perineal lacerations, in addition to seeking the best indications and techniques.

The protection of selective medio-lateral episiotomy against serious lacerations had already been previously demonstrated in large observational studies such as one by De Leeuw $^{33}$ that, after evaluating 284,783 deliveries in the Netherlands, concluded that this procedure strongly protected against third and fourth-degree lacerations (OR: 0.21 : CI: 0.20-0.23), while midline episiotomy was a risk factor.

In the review of the literature of the past 10 years we observed that of the 13 studies included in the analysis, five $e^{8,10,16,22,25}$ reported the protective role of selective episiotomy, especially when performed during an operative delivery. Three small studies ${ }^{11,23,24}$ confirmed the findings of the meta-analysis of the Cochrane Library that selective episiotomy has more benefits than routine episiotomy, and four studies reported no significant differences between the groups with or without episiotomy. ${ }^{12,19-21}$ It is worth emphasizing that these last four studies presented a much smaller sample size than the first five $(354,912$ versus 5,342 patients). Episiotomy was a risk factor for severe lacerations in only one of the studies assessed, ${ }^{9}$ but in this study the rate of midline episiotomy was of $78 \%$, confirming what was already present in the literature, that midline episiotomy is a risk and not a protective factor.

As for the risk factors for severe perineal lacerations, an operative delivery (either using a forceps or a vacuum extractor), fetal weight above $4 \mathrm{~kg}$, a prolonged second stage, and shoulder dystocia were the main risks, and appear to be the most important indications for episiotomy. Acute fetal distress was not evaluated, as it is considered a formal indication in all studies and should, therefore, be included in the list of indications. The variety of occipito-sacral positions was assessed by only two studies, but in our view this should also be an indication to be considered as it increases the detachment diameter, and the need of instrumental deliveries.

Primiparity, although being one of the most cited risk factors, should not be an absolute indication for episiotomy, otherwise we would return to the dilemma of routine versus selective episiotomy. We should, however, be more attentive to the need of an episiotomy procedure in these patients because they will have a higher risk of lacerations.
In a final analysis, the professionals who attend the delivery are the ones who should evaluate the degree of distensibility of the perineum and the need to perform episiotomy. Future studies should focus on ways to assess the strength and distensibility of the perineal structures before and during labor to try to improve the accuracy in predicting lesions. In addition, a more accurate evaluation should be performed during the pre-natal period, to assess the perineal muscles, their tonus, and the need for professional help for a better preparation for childbirth.

Another relevant aspect of the discussion on episiotomy is the technique. As observed, many obstetricians and midwives, in an attempt to execute the medio-lateral episiotomy, end up performing an almost midline episiotomy, thus increasing the risks for the patient. ${ }^{26-28}$

We believe that many of the risks attributed to episiotomy are, in fact, related to the use of an incorrect technique. Mclennan et $\mathrm{al}^{34}$ performed an interesting study by sending out questionnaires to all residents in the final year of Gynecology and Obstetrics training in the US. Of the respondents, $60 \%$ had never attended a theoretical class on episiotomy, and $59 \%$ had never attended a class on the pelvic floor. However, the most impressive finding was that $40 \%$ of them had already sutured over 20 third-degree lacerations and $7 \%$ over 20 fourth-degree lacerations, and only $28 \%$ of the sutures had been supervised. There is no way to expect that a procedure may achieve the maximum possible benefit if the people who execute it have no theoretical knowledge, nor practical supervision.

Still on the importance of experience in the performance of episiotomy, Shiono et $\mathrm{al}^{35}$ evaluated 27,300 deliveries performed in a large multicenter study in the US between 1959 and 1966. In this study, 38.4\% of births were performed by interns, $32.4 \%$ by residents, $17.8 \%$ by students, and $8.5 \%$ by obstetricians. The medio-lateral episiotomy was a protective factor against third- and fourth-degree lacerations (OR: $0.4 \mathrm{CI}$ : 0.2-0.9), while the midline episiotomy was a risk factor (OR: $4.2 \mathrm{CI}$ : 1.8-10.0). However, it is interesting that there were no cases of severe perineal laceration in the group of patients cared for by more experienced obstetricians when mediolateral episiotomy was performed, while only one case with midline episiotomy was observed.

The final technical aspect that is worth mentioning is the timing of the episiotomy. The literature ${ }^{36}$ tells us that this should be performed in the plane +2 of DeLee before the fetal head completely stretches the birth canal. Unfortunately, none of the assessed studies addressed this issue however, one study simulating the damage caused by the fetal head on the pelvic floor seems to confirm that to avoid the maximum stretching of the muscles, we should perform episiotomy earlier.

It is interesting to observe that Woolley, ${ }^{37}$ in a 1995 review article analyzing the study by Shiono et al, ${ }^{35}$ mentions variations in the technique, such as its more precocious implementation (in the plane +2 of DeLee), as one of the possible causes of the protective effect of episiotomy. 


\section{Conclusions}

This is a descriptive review and presents all the biases of this type of analysis. Unfortunately, the heterogeneity of the studies published in the literature does not allow the application of a systematic review on the theme. However, the evaluated data allow us to conclude that a well-justified episiotomy performed with a correct technique protects against severe perineal lacerations, preventing the occurrence of important sequelae such as fecal incontinence. If performing episiotomy in all patients is not beneficial, the failure to perform episiotomy when there is an indication may be just as detrimental.

\section{References}

1 Thacker SB, Banta HD. Benefits and risks of episiotomy: an interpretative review of the English language literature, 18601980. Obstet Gynecol Surv 1983;38(6):322-338

2 DeLee JB. The prophylactic forceps operation. Am J Obstet Gynecol 1920;1(1):34-44

3 Carroli G, Mignini L. Episiotomy for vaginal birth. Cochrane Database Syst Rev 2009;(1):CD000081

4 Goldberg J, Holtz D, Hyslop T, Tolosa JE. Has the use of routine episiotomy decreased? Examination of episiotomy rates from 1983 to 2000. Obstet Gynecol 2002;99(3):395-400

5 Gurol-Urganci I, Cromwell DA, Edozien LC, et al. Third- and fourthdegree perineal tears among primiparous women in England between 2000 and 2012: time trends and risk factors. BJOG 2013;120(12):1516-1525

6 Räisänen S, Cartwright R, Gissler M, et al. Changing associations of episiotomy and anal sphincter injury across risk strata: results of a population-based register study in Finland 2004-2011. BMJ Open 2013;3(8):1-8

7 Bradley CS, Richter HE, Gutman RE, et al; Pelvic Floor Disorders Network. Risk factors for sonographic internal anal sphincter gaps 6-12 months after delivery complicated by anal sphincter tear. Am J Obstet Gynecol 2007;197(3):310.e1-310.e5

8 Revicky V, Nirmal D, Mukhopadhyay S, Morris EP, Nieto JJ. Could a mediolateral episiotomy prevent obstetric anal sphincter injury? Eur J Obstet Gynecol Reprod Biol 2010;150(2):142-146

9 Landy HJ, Laughon SK, Bailit JL, et al; Consortium on Safe Labor. Characteristics associated with severe perineal and cervical lacerations during vaginal delivery. Obstet Gynecol 2011;117(3):627-635

10 Aukee P, Sundström H, Kairaluoma MV. The role of mediolateral episiotomy during labour: analysis of risk factors for obstetric anal sphincter tears. Acta Obstet Gynecol Scand 2006;85(7):856-860

11 Moini A, Yari RE, Eslami B. Episiotomy and third- and fourthdegree perineal tears in primiparous Iranian women. Int J Gynaecol Obstet 2009;104(3):241-242

12 Eskandar O, Shet D. Risk factors for 3rd and 4th degree perineal tear. J Obstet Gynaecol 2009;29(2):119-122

13 Stedenfeldt M, Øian P, Gissler M, Blix E, Pirhonen J. Risk factors for obstetric anal sphincter injury after a successful multicentre interventional programme. BJOG 2014;121(1):83-91

14 Gottvall K, Allebeck P, Ekéus C. Risk factors for anal sphincter tears: the importance of maternal position at birth. BJOG 2007; 114(10):1266-1272

15 Dahlen HG, Ryan M, Homer CS, Cooke M. An Australian prospective cohort study of risk factors for severe perineal trauma during childbirth. Midwifery 2007;23(2):196-203

16 Räisänen S, Selander T, Cartwright R, et al. The association of episiotomy with obstetric anal sphincter injury-a population based matched cohort study. PLoS ONE 2014;9(9):1-7
17 Jangö H, Langhoff-Roos J, Rosthøj S, Sakse A. Modifiable risk factors of obstetric anal sphincter injury in primiparous women: a population-based cohort study. Am J Obstet Gynecol 2014; 210(1):59.e1-59.e6

18 Jangö $\mathrm{H}$, Langhoff-Roos J, Rosthøj S, Sakse A. Risk factors of recurrent anal sphincter ruptures: a population-based cohort study. BJOG 2012;119(13):1640-1647

19 Fritel X, Schaal JP, Fauconnier A, Bertrand V, Levet C, Pigné A. Pelvic floor disorders 4 years after first delivery: a comparative study of restrictive versus systematic episiotomy. BJOG 2008;115(2): 247-252

20 Murphy DJ, Macleod M, Bahl R, Goyder K, Howarth L, Strachan B. A randomised controlled trial of routine versus restrictive use of episiotomy at operative vaginal delivery: a multicentre pilot study. BJOG 2008;115(13):1695-1702, discussion 1702-1703

21 Macleod M, Strachan B, Bahl R, et al. A prospective cohort study of maternal and neonatal morbidity in relation to use of episiotomy at operative vaginal delivery. BJOG 2008;115(13):1688-1694

22 de Leeuw JW, de Wit C, Kuijken JP, Bruinse HW. Mediolateral episiotomy reduces the risk for anal sphincter injury during operative vaginal delivery. BJOG 2008;115(1):104-108

23 Islam A, Hanif A, Ehsan A, Arif S, Niazi SK, Niazi AK. Morbidity from episiotomy. J Pak Med Assoc 2013;63(6):696-701

24 Sulaiman AS, Ahmad S, Ismail NA, Rahman RA, Jamil MA, Mohd Dali AZ. A randomized control trial evaluating the prevalence of obstetrical anal sphincter injuries in primigravida in routine versus selective mediolateral episiotomy. Saudi Med J 2013; 34(8):819-823

25 Hauck YL, Lewis L, Nathan EA, White C, Doherty DA. Risk factors for severe perineal trauma during vaginal childbirth: a Western Australian retrospective cohort study. Women Birth 2015;28(1): $16-20$

26 Andrews V, Thakar R, Sultan AH, Jones PW. Are mediolateral episiotomies actually mediolateral? BJOG 2005;112(8): 1156-1158

27 Eogan M, Daly L, O'Connell PR, O'Herlihy C. Does the angle of episiotomy affect the incidence of anal sphincter injury? BJOG 2006;113(2):190-194

28 Kalis V, Karbanova J, Horak M, Lobovsky L, Kralickova M, Rokyta Z. The incision angle of mediolateral episiotomy before delivery and after repair. Int J Gynaecol Obstet 2008;103(1):5-8

29 Stedenfeldt M, Pirhonen J, Blix E, Wilsgaard T, Vonen B, Øian P. Episiotomy characteristics and risks for obstetric anal sphincter injuries: a case-control study. BJOG 2012;119(6):724-730

30 Gonzalez-Díaz E, Moreno Cea L, Fernández Corona A. Trigonometric characteristics of episiotomy and risks for obstetric anal sphincter injuries in operative vaginal delivery. Int Urogynecol J 2015;26(2):235-242

31 Parente MP, Natal Jorge RM, Mascarenhas T, Silva-Filho AL. The influence of pelvic muscle activation during vaginal delivery. Obstet Gynecol 2010;115(4):804-808

32 Muniz BMV, Barbosa RM. Problematizando o atendimento ao parto: cuidado ou violência? Actas de Memorias Convención Internacional de Salud Pública; 2012 dic 3-7; La Habana, Cuba. p. 1-11.

33 de Leeuw JW, Struijk PC, Vierhout ME, Wallenburg HCS. Risk factors for third degree perineal ruptures during delivery. BJOG 2001;108(4):383-387

34 McLennan MT, Melick CF, Clancy SL, Artal R. Episiotomy and perineal repair. An evaluation of resident education and experience. J Reprod Med 2002;47(12):1025-1030

35 Shiono P, Klebanoff MA, Carey JC. Midline episiotomies: more harm than good? Obstet Gynecol 1990;75(5):765-770

36 Corrêa MD, Corrêa Junior MD. Assistência ao parto. In: Corrêa MD, Melo VH, Aguiar RALP, Corrêa Junior MD, editores. Noções práticas de obstetrícia. 14a ed. Belo Horizonte: Coopmed; 2011. p. 867-94.

37 Woolley RJ. Benefits and risks of episiotomy: a review of the English-language literature since 1980. Part I. Obstet Gynecol Surv 1995;50(11):806-820 